\title{
Potential Use of High Pressure Homogenized Hazelnut Beverage for a Functional Yoghurt-Like Product
}

\author{
OSMAN GUL, ILYAS ATALAR, MUSTAFA MORTAS, FURKAN TURKER SARICAOGLU, \\ AYSEGUL BESIR, LATIFE BETUL GUL \& FEHMI YAZICI
}

\begin{abstract}
Hazelnut beverage is a plant-based beverage produced from hazelnut cake as a by-product obtained after cold press extraction. It has high nutritional value and a significant percentage of consumers show interest in it due to its health benefits. In this study, hazelnut beverage manufactured from by-products of hazelnut oil industry was incorporated into functional yoghurt production. Five formulations (ratio of 1/0, 3/1, $2 / 1,1 / 1,0 / 1, v / v$, cow milk/hazelnut beverage) of yoghurt-like products were prepared to indicate the storage period of the samples and the analysis performed. For yoghurt

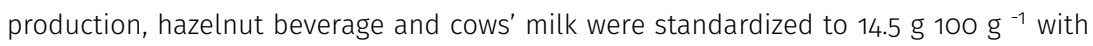
skimmed milk powder. The use of hazelnut beverage in yoghurt production negatively affected L. bulgaricus counts. Water holding capacity and viscosity values were improved by using hazelnut beverage. Increasing hazelnut beverage concentration led to an increase in the total phenolic compounds and antioxidant activity, malic acid levels and also unsaturated fatty acids, especially oleic and linoleic acid. Using the ratio of $3 / 1$ was found the best in view of appearance, flavor and overall acceptability. Based on the structural, rheological and sensorial properties, this study could guide the dairy industry to use hazelnut beverage obtained from hazelnut cake.
\end{abstract}

Key words: fruit crops, functional properties, hazelnut beverage, rheology, structure, yoghurt.

\section{INTRODUCTION}

Yoghurt is a fermented dairy product, commonly made from cow's milk by the proto-cooperative action of two lactic acid bacteria of Lactobacillus delbrueckii subsp. bulgaricus and Streptococcus thermophilus (Isanga \& Zhang 2009). Over the last decades, there has been an increasing demand for dairy alternative products due to health problems associated with lactose intolerance, cholesterol content and allergenic milk proteins (Santos et al. 2014). Consumption of functional foods is also increasing due to consumers' awareness of the importance of a healthy diet (Aboulfazli \& Baba 2015). Plant-based beverages have a good potential to fulfill these expectations and to act as a potential source for functional compounds like antioxidants and dietary fiber (Luana et al. 2014). Recently, a few studies about manufacturing yoghurt-like products by using soy beverage (Donkor et al. 2007), corn beverage (Supavititpatana et al. 2008), peanut beverage (Isanga \& Zhang 2009) and mango-soy beverage (Kumar \& Mishra 2004) have been reported. By-products from hazelnut oil processing are 
not generally used for human nutrition due to the treatment with chemicals in the extraction step. In contrast, cold press extraction is the only oil production method without heat or solvent treatment. It has a major advantage in minimizing the degradation of nutritive constituents. In a previous study, hazelnut beverage was manufactured from by-product of cold pressing process. Microstructure and rheological properties of hazelnut beverage are improved by applying high-pressure homogenization and a drinkable vegetable beverage is characterized (Gul et al. 2017). Several works have been reported about the manufacture of fermented beverage from hazelnut slurry (oil not removed) obtained from hazelnut by grounding with water (Bernat et al. 2014, Ilyasoğlu et al. 2015, Maleki et al. 2015, Ozturkoglu-Budak et al. 2016, Atalar 2019). In this study, the potential usage of hazelnut beverage produced from cold-pressed hazelnut cake for yoghurt production was investigated in terms of its physicochemical, microbiological, rheological and bioactive properties. It was also aimed to utilize by-products of oil industry for human nutrition, thereby reducing industrial waste.

\section{MATERIALS AND METHODS}

\section{Materials}

Hazelnut kernels (skin removal) were obtained from Gursoy Hazelnut Production Factory (Ordu, Turkey). The oil was removed from hazelnut kernels by using a headed cold press machine (Ekotok 1, Izmir, Turkey) and obtained cold press hazelnut cake (8.77\% moisture, $45.62 \%$ protein, $23.89 \%$ carbohydrate, $16.93 \%$ lipid, and $4.79 \%$ ash) was used as the main ingredient for hazelnut beverage production. Cow's milk was purchased from Pilot Dairy Plant of Ondokuz Mayis University and the milk used for the yoghurt production had $6.7 \mathrm{pH}, 12.36 \%$ total solid content, 3.58\% fat and 3.81\% protein which were determined according to Bradley et al. (1992). Skimmed milk powder was purchased from a dairy factory (Pinar Dairy Co., Izmir, Turkey). The yoghurt starter culture (YO-MIX 511 LYO 100 DCU) was obtained from Danisco (Paris, France). All reagents and solvents (analytical grade or HPLC grade) were purchased from Merck (Darmstadt, Germany). FAME mix, organic acid standards, ABTS and gallic acid were obtained from Sigma-Aldrich (St. Louis, MO, USA).

\section{Preparation of hazelnut beverage}

Hazelnut beverage was prepared by a method reported earlier (Gul et al. 2018) with slight modifications. Hazelnut cake was grounded using a blender (Waring laboratory blender, Conair Corporation, Stamfold, CT, USA) for 10 min. Obtained hazelnut flour was mixed with distilled water at a ratio of 1.25:10 (w/v) and homogenized using an Ultra-Turrax homogenizer (IKA-Werke GmbH \& Co. KG, Staufen, Germany) for 10 min at 10,000 rpm. High-pressure homogenization treatment was carried out using a double stage high-pressure homogenizer (Panda PLUS 2000, GEA Niro Soavi, Parma, Italy) operated at $100 \mathrm{MPa}$ pressure. Hazelnut beverage passed only 1 time through the homogenizer. The temperature of the samples after the homogenization process was measured as $38 \stackrel{\circ}{ } \mathrm{C}( \pm 3 \stackrel{\circ}{ } \mathrm{C})$. The chemical composition of the produced hazelnut beverage was as follows: $6.48 \mathrm{pH}, 12.41 \%$ total solids, 4.71\% protein, $1.45 \%$ lipid, 3.03\% carbohydrate and 0.62\% ash. 


\section{Yoghurt preparation}

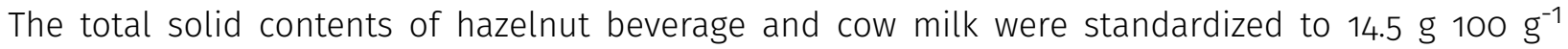
by adding skimmed milk powder and then mixed at a ratio of $1 / 0,3 / 1,2 / 1,1 / 1$ and $0 / 1(\mathrm{~V} / \mathrm{V}$, cow milk/hazelnut beverage) and coded as A, B, C, D and E respectively. Each mixture was homogenized under pressure of $25 \mathrm{MPa}$ at $65 \stackrel{\circ}{\circ}$ and then heated at $90 \stackrel{\circ}{\circ}$ for $10 \mathrm{~min}$. The pasteurized milk was rapidly cooled to 45 ㅇ $\mathrm{C}$ in a water bath and then inoculated with $3 \mathrm{~mL} 100 \mathrm{~mL}^{-1}$ starter yoghurt culture (Streptococcus thermophilus and Lactobacillus bulgaricus). Incubation was carried out at 43 o $\mathrm{C}$ for 4-5 h until $\mathrm{pH}$ was 4.5 . Samples were analyzed at the $1^{\text {st }}, 7^{\text {th }}, 14^{\text {th }}$, and $21^{\text {st }}$ days of storage.

\section{Chemical analysis}

The $\mathrm{pH}$ of the samples was measured with a pH meter (Eutech Cyberscan pH 2700, Ayer Rajah Crescent, Singapore) by directly submerging the probe into the yoghurt samples. The AOAC methods (AOAC 1995) were used for proximate analyzes of yoghurt samples as moisture content, total fat content, and protein content. A multiplication factor of 6.38 was used to convert nitrogen percentage into protein percentage. The peroxide value was determined using a modified method of Ghorbanzade et al. (2017). An amount of $1 \mathrm{~g}$ of extracted oil sample was dissolved in $25 \mathrm{~mL}$ of chloroform : acetic acid at $2 / 3(\mathrm{v} / \mathrm{v})$ and $1 \mathrm{~mL}$ of saturated potassium iodide were added. The mixture was shaken for $1 \mathrm{~min}$ and then kept in the dark for 6 min. After adding distilled water $(75 \mathrm{~mL})$ and starch solution $(1 \mathrm{~mL}, 1 \%, \mathrm{w} / \mathrm{v})$, the mixture was titrated with sodium thiosulfate $(0.01 \mathrm{~N})$ until transparent. The peroxide values were expressed as miliequivalent peroxide $\mathrm{kg}^{-1}$ sample.

\section{Microbiological analysis}

Yoghurt samples $(10 \mathrm{~g})$ were diluted in $90 \mathrm{~mL}$ of sterile sodium thiosulfate solution (0.2\% w/v) and homogenized for 3 min using a stomacher (Smasher, AES Chemunex, Bruz, France). Serial dilutions were made using a Ringer solution (Merck, Darmstadt, Germany). The enumeration of S. thermophilus was performed using M17 agar (Merck, Darmstadt, Germany), and the plates were incubated aerobically at 37 으 for 48 h. L. bulgaricus population were counted on MRS agar (Merck, Darmstadt, Germany) adjusted to pH 5.2 with acetic acid under anaerobic incubation in an anaerobic jar at 45 o $\mathrm{C}$ for $72 \mathrm{~h}$. Yeast and moulds were enumerated by using YGC agar (Merck, Darmstadt, Germany) at 25 o $\mathrm{C}$ for $5 \mathrm{~d}$. The enumeration of microorganisms was performed in triplicate and cell concentration was expressed as $\log$ CFU g ${ }^{-1}$ of yoghurt.

\section{Water-holding capacity (WHC) analysis}

The WHC of yoghurt samples was measured according to the method described by Isanga \& Zhang (2009) with slight modifications. Twenty grams of yoghurt were weighed into a $50 \mathrm{~mL}$ test tube and centrifuged (Nüve-Bench Top Centrifuge, NF 1200R, Turkey) at 3,250 x g for 20 min at 4 oC. The percentage of WHC was defined as:

$$
W H C=\left(1-W_{1} / W_{2}\right) \times 100
$$

where, $W_{1}$ is the weight of whey after centrifugation, $W_{2}$ is the weight of sample. 


\section{Rheological analysis}

Rheological analyses of yoghurt samples were measured by using Haake Mars III rheometer (Thermo Scientific, Germany) with cone and plate geometry (35 mm diameter, 20 angle) and the gap between cone and plate was set at $0.106 \mathrm{~mm}$. Measurements were performed in the shear rate range of 1-100 $\mathrm{S}^{-1}$ at 20 으. The flow behaviors of the samples were described by Ostwald de Waele model (2) using Rheowin Data Manager Software (version 4.20, Haake):

$$
\eta \text { napp }=K^{(\mathrm{n}-1)}
$$

where, napp is apparent viscosity $(P a . s), \gamma$ the shear rate $\left(s^{-1}\right), K$ the consistency index $\left(P a . s^{n}\right)$ and $n$ the flow behavior index (dimensionless). Each measurement was repeated three times for each sample. The apparent viscosity values of yoghurt samples were evaluated the specified shear rate of $50 \mathrm{~s}^{-1}$ indicates shear rate in mouth.

\section{Color properties}

The color properties ( $L^{*}$, lightness; $a^{*}$, red-green; $b^{*}$, yellow-blue) of yoghurt samples were measured using a calorimeter (Minolta Chroma Meter, CR-400, Osaka, Japan). Color of the samples was characterized as Whiteness Index (WI) by following equations (3):

$$
W I=100-\sqrt{\left(100-L^{*}\right)^{2}+\left(a^{*}\right)^{2}+\left(b^{*}\right)^{2}}
$$

\section{Phenolic compounds and antioxidant activity}

The extraction of phenolic compounds from yoghurt samples was carried out using a modified method of Bertolino et al. (2015). Yoghurt sample (10 g) diluted with $2.5 \mathrm{~mL}$ of distilled water was centrifuged (Nuve-Bench Top Centrifuge, NF 1200R, Turkey) at 8,000 x g for 30 min at $4^{\circ} \mathrm{C}$. Suspensions were filtered with Whatman filter paper no. 1 and the filtrate was used for total phenolic content (TPC) and 1,1-diphenyl-2-picrylhydrazil (DPPH) analysis. The TPC was determined according to Ilyasoğlu et al. (2015), with some modifications. Briefly, $0.5 \mathrm{~mL}$ of extract was mixed with $2.5 \mathrm{~mL}$ of Folin Ciocelteau's phenol reagent $(0.2 \mathrm{~N}$ ) and $2 \mathrm{~mL}$ of sodium carbonate. After the incubation of $2 \mathrm{~h}$ at room temperature, the absorbance of the mixture was measured at $760 \mathrm{~nm}$ using a UV/VIS spectrophotometer (Thermo Fisher, G10S UV-Vis, USA) against $1 \mathrm{~mL}$ of distilled water as blank. The TPC value was assessed based on plots of a gallic acid calibration curve (linearity range: 5-100 $\mathrm{mg} \mathrm{L}^{-1} ; R^{2}=0.998$ ) and results were expressed as $\mu \mathrm{g}$ gallic acid equivalents (GAEs) per gram of sample. The DPPH radical scavenging activity of the extracts was measured according to the method of Maleki et al. (2015), with some modifications. Briefly, $0.1 \mathrm{~mL}$ of extract was added to $4.9 \mathrm{~mL}$ of a $6.1 \times 10^{-5} \mathrm{M}$ DPPH solution and vortexed for 0.5 min. After the incubation for $2 \mathrm{~h}$ in the dark at room temperature, the mixture was centrifuged at $3,000 \times \mathrm{g}$ for $10 \mathrm{~min}$ and then, the absorbance was recorded against methanol as control at $517 \mathrm{~nm}$ by a spectrophotometer (Thermo Fisher, G10S UV-Vis, USA). The scavenging activity was calculated according to the formula (4):

$$
\text { DPPH scavenging activity }(\%)=\left(\left(A_{C}-A_{S}\right) / A_{C}\right) \times 100
$$


where $A c$ is the absorbance of the control (methanol) and As is the absorbance of the sample. The results were stated as $\mu M$ Trolox equivalents (TE) per gram of sample. The calibration curve linearity range was 5-100 $\mathrm{mg} \mathrm{L}^{-1}\left(R^{2}=0.999\right)$.

\section{Organic acid composition}

To measure organic acid compositions, $5 \mathrm{~g}$ of each yoghurt samples was mixed with $25 \mathrm{~mL}$ of $\mathrm{H}_{2} \mathrm{SO}_{4}$ ( $0.01 \mathrm{~N}$ ) followed by centrifuging (Sigma 3K30, Germany) at 7,000 g 4 으 for 7 min. The clear supernatant was removed and filtered with a nylon disc filter (Supelco Iso-DiscTM Filters, N-25-4 Nylon, 25 mm x 0.45 $\mu \mathrm{m})$ and transferred into vials. Organic acids were determined by high-pressure liquid chromatography (HPLC) (Agilent, 1260, Germany) system consisting of an autosampler, pump, temperature-controlled column oven and UV detector. The analytical separation of acids was performed with Shim-pack 150 mm, $4.6 \mathrm{~mm}$ i.d ODS-3 column. As a mobile phase, $10 \mathrm{mM}$ perchloric acid was used and analysis conditions were arranged as $0.5 \mathrm{~mL} \mathrm{~min}^{-1}$ isocratic flow rate; 35 oC oven temperature; $210 \mathrm{~nm}$ wavelength; $20 \mu \mathrm{L}$ sample injection volume. Individual organic acids were identified by comparing elution times with standard solutions elution times and also the quantification of acids was performed using calibration curves obtained from standard solutions (Gul et al. 2015).

\section{Fatty acid composition}

The fatty acid composition was determined using gas chromatography (GC) after the esterification of cold extracted fat according to a study performed by Dervisoglu et al. (2013) with some modifications. To perform fatty acid profile, yoghurt samples were initially cold extracted. Each yoghurt sample (50

g) was centrifuged at $4000 \mathrm{rpm}$ for $15 \mathrm{~min}$ and then, supernatant was removed. Ten grams of kieselgel powder and $100 \mathrm{~mL}$ of ether were added to the precipitated part. After mixing step, the mix was filtered through a filter paper. Purification of fat was conducted by using Rotary evaporator (Buchi Rotavapor, R-200, Switzerland) at $80 \mathrm{mPa}$ vacuum conditions. After the cold extraction, $0.4 \mathrm{~mL}$ of pure fat was mixed with $4 \mathrm{~mL}$ of 2,2,4-trimetilpentan for $30 \mathrm{~s}$ and then stored at dark conditions for $6 \mathrm{~min}$. Two $\mathrm{mL}$ of $\mathrm{KOH}(2 \mathrm{~N})$ was added and then neutralized with $\mathrm{HCl}(1 \mathrm{~N})$. After the phase separation, the top layer was taken and analyzed in GC (Shimadzu, Japan). Supelco DB 88 capillary column (60 m X 0.25 mm i.d., $0.25 \mu \mathrm{m}$ ) (J \& W Scientific, Folson, CA, USA) and flame ionization detector (FID) were used to perform analysis. The identification of fatty acid methyl esters was performed by using standard fatty acid methyl esters reference mixture (Supelco 37 Component FAME Mixture, Bellefonte, PA, USA) and fatty acids were expressed as a percentage weight of the amount of total fatty acids.

\section{Sensory properties}

Sensory evaluation was assessed by sixteen semi-trained panelists (7 males and 9 females, age range 23-50) including both staff and students of the Department of Food Engineering, Ondokuz Mayis University throughout the storage period. The samples $(20 \mathrm{~g})$ were served at approximately 6-8 $0 \mathrm{C}$ in transparent plastic cups coded with random three-digit numbers in a completely randomized order. Sensory attributes of yoghurt samples were evaluated in terms of flavor, consistency, appearance, and overall acceptability with maximum scores of 10,5, 5 and 10, respectively. A structured ten or five-point 
hedonic scale ranging from "like extremely" to "dislike extremely" was used to numerically describe the sensory properties.

\section{Statistical analysis}

All experiments were performed in three series and in duplicate. Results were expressed as mean \pm standard deviation. The results were analyzed with one-way ANOVA to determine the significant differences between yoghurt samples and storage days. The results were compared by Duncan multiple range tests with a confidence interval set at 95\%.

\section{RESULTS AND DISCUSSION}

\section{Physicochemical properties}

The physicochemical properties of yoghurt samples during 21 days of storage were shown in Table I. The $\mathrm{pH}$ values of the yoghurt samples ranged from 4.49 to 4.61 on the first day of storage. After the fermentation, $\mathrm{pH}$ value of sample $\mathrm{E}$ was lower than the other yoghurts and there was no significant difference among the other yoghurt samples ( $P>0.05$ ). This result could be attributed to the higher buffer capacity of cows' milk. Sunny-Roberts et al. (2004) reported that the final pH of fermented groundnut beverage was found within the acceptable ranges of 4-4.5 after $36 \mathrm{~h}$ incubation. When compared to soy beverage and cow's milk yoghurts, it was found that the drop in $\mathrm{pH}$ during fermentation was faster in the soy beverage than in cow's milk; however, the final pH of yoghurts was found similar (Farnworth et al. 2007). During storage, the change in pH was found to be more stable in sample E. This result might be related to the limited availability of lactose required for the growth of microorganisms throughout storage. Bertolino et al. (2015) reported that the $\mathrm{pH}$ value of yoghurts was not related to the added hazelnut skin and ranged from 4.46 to 4.52 . The authors also indicated that skin added yoghurts show a slight decrease in $\mathrm{pH}$ ( 0.19 and 0.28 units) during storage as in our findings. The $\mathrm{pH}$ reduction of yoghurts has an important role in the prediction of the shelf life of yoghurts. The addition of hazelnut beverage to yoghurt formula may become an important tool for extending the shelf life. As shown in Table I, titration acidity values of yoghurt samples at the $1^{\text {st }}$ day of storage ranged from $0.76 \%$ to $0.88 \%$ (expressed as \% lactic acid) and the highest titratable acidity was found only in sample $\mathrm{E}(\mathrm{P}<0.05)$, consistent with $\mathrm{pH}$ results. The highest fat content was determined as $3.19 \%$ in sample A. Addition of hazelnut beverage reduced the fat contents of yoghurt samples $(\mathrm{P}<0.05)$. The reduction in fat content could be considered as an advantage for the preservation of yogurt quality since the development of rancidity may be retarded. The highest protein content (5.49\%) was achieved in sample $E$ and the use of cow milk resulted in a decrease in the protein content of the yoghurts $(P<0.05)$. As shown in Table I, sample $E$ had significantly higher peroxide values (2.23 meq $\mathrm{kg}^{-1}$ ) than the other samples $(P<0.05)$, while the peroxide value was not detected in samples $A$ and $B$ after yoghurt production. The use of hazelnut beverage for yoghurt production caused an increase in peroxide value $(P<0.05)$. Similar results were found in previous studies which reported that peroxide value of yoghurt increase with purple rice bran oil (Alfaro Sanabria 2012) and rice bran (Demirci et al. 2017). The peroxide value increased along with storage time. At the end of storage time, control sample had the lowest peroxide value as $2.03 \mathrm{meq} \mathrm{kg}^{-1}$ while sample $\mathrm{E}$ had the highest peroxide value as 4.43 meq $\mathrm{kg}^{-1}$. One of the major concerns in food quality deterioration is lipid oxidation and off-flavor can 
be developed during the oxidative process (Tseng \& Zhao 2013). Considering sensory evaluation, all yoghurt samples could be consumed because panelists did not detect subjectively off-flavor in all yoghurt samples during the storage period.

Table I. Physicochemical properties of yoghurt-like product produced with cow milk and hazelnut beverage during storage at $4^{\circ} \mathrm{C}$.

\begin{tabular}{|c|c|c|c|c|c|}
\hline \multirow[b]{2}{*}{ Physicochemical Properties } & \multicolumn{5}{|c|}{ Storage time (days) } \\
\hline & Samples (v/v)* & 1 & 7 & 14 & 21 \\
\hline \multirow{5}{*}{$\mathrm{pH}$} & $A$ & $4.61 \pm 0.02^{\mathrm{aA}}$ & $4.38 \pm 0.04^{\mathrm{dB}}$ & $4.35 \pm 0.01^{\mathrm{bB}}$ & $4.29 \pm 0.06^{b B}$ \\
\hline & $\mathrm{B}$ & $4.56 \pm 0.05^{\mathrm{aA}}$ & $4.33 \pm 0.01^{\mathrm{cdB}}$ & $4.22 \pm 0.04^{\mathrm{cC}}$ & $4.20 \pm 0.03^{\mathrm{cC}}$ \\
\hline & $C$ & $4.59 \pm 0.01^{\mathrm{aA}}$ & $4.43 \pm 0.01^{\mathrm{bB}}$ & $4.45 \pm 0.04^{\mathrm{aB}}$ & $4.34 \pm 0.02^{a b c}$ \\
\hline & $\mathrm{D}$ & $4.58 \pm 0.03^{\mathrm{aA}}$ & $4.36 \pm 0.03^{\mathrm{CB}}$ & $4.34 \pm 0.03^{b B}$ & $4.30 \pm 0.02^{b B}$ \\
\hline & $\mathrm{E}$ & $4.49 \pm 0.04^{\mathrm{bA}}$ & $4.50 \pm 0.02^{\mathrm{aA}}$ & $4.37 \pm 0.01^{b B}$ & $4.39 \pm 0.02^{\mathrm{aB}}$ \\
\hline \multirow{5}{*}{ Titratable acidity (\% lactic acid) } & A & $0.76 \pm 0.01^{\mathrm{aB}}$ & $1.16 \pm 0.07^{\mathrm{aA}}$ & $1.23 \pm 0.07^{\mathrm{aA}}$ & $1.17 \pm 0.06^{\mathrm{bA}}$ \\
\hline & $\mathrm{B}$ & $0.83 \pm 0.03^{\mathrm{aC}}$ & $1.13 \pm 0.01^{\mathrm{aB}}$ & $1.17 \pm 0.03^{\mathrm{aB}}$ & $1.25 \pm 0.02^{\mathrm{aA}}$ \\
\hline & $C$ & $0.86 \pm 0.01^{\mathrm{aB}}$ & $1.03 \pm 0.02^{\mathrm{bA}}$ & $1.05 \pm 0.01^{b A}$ & $1.08 \pm 0.05^{\mathrm{CA}}$ \\
\hline & $D$ & $0.83 \pm 0.03^{b c}$ & $0.98 \pm 0.01^{\mathrm{bB}}$ & $1.01 \pm 0.06^{\mathrm{bB}}$ & $1.16 \pm 0.02^{\mathrm{bA}}$ \\
\hline & $E$ & $0.88 \pm 0.02^{\mathrm{eA}}$ & $0.86 \pm 0.02^{\mathrm{CA}}$ & $0.88 \pm 0.03^{c A}$ & $0.89 \pm 0.01^{\mathrm{dA}}$ \\
\hline \multirow{5}{*}{ Fat (\%) } & A & $3.19 \pm 0.03^{\mathrm{aA}}$ & $3.23 \pm 0.18^{\mathrm{aA}}$ & $3.27 \pm 0.15^{\mathrm{aA}}$ & $3.23 \pm 0.1^{\mathrm{aA}}$ \\
\hline & $\mathrm{B}$ & $2.98 \pm 0.1^{\mathrm{bA}}$ & $3.05 \pm 0.06^{\mathrm{aA}}$ & $3.03 \pm 0.06^{\mathrm{aA}}$ & $3.06 \pm 0.09^{\mathrm{bA}}$ \\
\hline & C & $2.78 \pm 0.23^{\mathrm{bA}}$ & $2.83 \pm 0.11^{\mathrm{bA}}$ & $2.83 \pm 0.06^{\mathrm{bA}}$ & $2.87 \pm 0.08^{\mathrm{bA}}$ \\
\hline & $\mathrm{D}$ & $2.38 \pm 0.05^{\mathrm{CA}}$ & $2.42 \pm 0.03^{C A}$ & $2.44 \pm 0.07^{\mathrm{CA}}$ & $2.4 \pm 0.05^{\mathrm{CA}}$ \\
\hline & $E$ & $1.4 \pm 0.1^{\mathrm{dB}}$ & $1.53 \pm 0.05^{\mathrm{dAB}}$ & $1.53 \pm 0.06^{\mathrm{dA}}$ & $1.6 \pm 0.1^{\mathrm{dA}}$ \\
\hline \multirow{5}{*}{ Protein (\%) } & $A$ & $4.67 \pm 0.05^{\mathrm{bcA}}$ & $4.7 \pm 0.1^{\mathrm{cdA}}$ & $4.76 \pm 0.05^{\mathrm{CA}}$ & $4.66 \pm 0.07^{\mathrm{CA}}$ \\
\hline & $\mathrm{B}$ & $4.59 \pm 0.15^{\mathrm{CA}}$ & $4.57 \pm 0.08^{\mathrm{dA}}$ & $4.48 \pm 0.04^{\mathrm{dA}}$ & $4.45 \pm 0.07^{\mathrm{dA}}$ \\
\hline & C & $4.76 \pm 0.11^{\mathrm{bA}}$ & $4.81 \pm 0.12^{\mathrm{CA}}$ & $4.55 \pm 0.08^{\mathrm{dB}}$ & $4.59 \pm 0.05^{\mathrm{cdB}}$ \\
\hline & $\mathrm{D}$ & $5.32 \pm 0.06^{\mathrm{aA}}$ & $5.13 \pm 0.05^{\mathrm{bB}}$ & $5.12 \pm 0.06^{b B}$ & $5.03 \pm 0.18^{b B}$ \\
\hline & $E$ & $5.49 \pm 0.13^{\mathrm{aA}}$ & $5.68 \pm 0.15^{\mathrm{aA}}$ & $5.56 \pm 0.08^{\mathrm{aA}}$ & $5.61 \pm 0.06^{\mathrm{aA}}$ \\
\hline \multirow{5}{*}{ Peroxide (meq $\mathrm{kg}^{-1}$ ) } & $A$ & $N D^{* *}$ & $0.84 \pm 0.08^{\mathrm{dB}}$ & $1.45 \pm 0.06^{\mathrm{dB}}$ & $2.03 \pm 0.13^{\mathrm{eA}}$ \\
\hline & $B$ & ND & $1.17 \pm 0.06^{\mathrm{CC}}$ & $2.05 \pm 0.05^{\mathrm{CB}}$ & $2.52 \pm 0.12^{d A}$ \\
\hline & $C$ & $1.09 \pm 0.06^{c D}$ & $1.83 \pm 0.12^{b C}$ & $2.31 \pm 0.13^{b B}$ & $2.83 \pm 0.06^{\mathrm{CA}}$ \\
\hline & $\mathrm{D}$ & $1.34 \pm 0.09^{b D}$ & $1.99 \pm 0.09^{b C}$ & $2.64 \pm 0.11^{\mathrm{bB}}$ & $3.36 \pm 0.09^{b A}$ \\
\hline & $\mathrm{E}$ & $2.23 \pm 0.11^{\mathrm{aC}}$ & $2.26 \pm 0.13^{\mathrm{aC}}$ & $3.48 \pm 0.12^{\mathrm{aB}}$ & $4.43 \pm 0.14^{\mathrm{aA}}$ \\
\hline
\end{tabular}

a,b,c,d Means in the same column with different lowercase letters show significant differences between samples $(P<0.05)$. A, B, C, D Means in the same row with different uppercase letters show significant differences 636 between storage periods $(P<0.05)$. * The samples of $A, B, C, D$, and $E$ indicate a ratio of $1 / 0,3 / 1,2 / 1,1 / 1$ and $O / 1$ ( $v / v$, cow milk/hazelnut beverage), respectively. ${ }^{* *}$ Not detected. 


\section{Microbiological analysis}

Viable counts of S. thermophilus and L. delbrueckii subsp. bulgaricus in yogurts produced using cow and hazelnut beverage were shown in Fig. $1 a$ and $1 b$, respectively. On the first day of cold storage, the

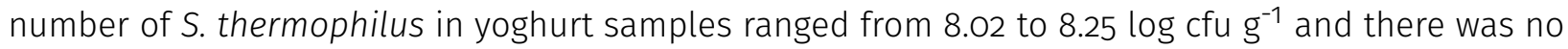
significant difference in the cell counts between samples ( $P>0.05$ ). At the end of the fermentation, the number of $S$. thermophilus in all yoghurt samples was higher than the recommended level in Codex Alimentarius $\left(10^{7} \mathrm{cfu} \mathrm{g}^{-1}\right)$. The obtained results are consistent with the results of hazelnut skin added yoghurts (8.38-8.67 log cfu g ${ }^{-1}$ ) (Bertolino et al. 2015) and yoghurts made with soy beverage (8.3 log cfu $\mathrm{g}^{-1}$ ) (Farnworth et al. 2007), but higher than the findings of yoghurt-like product manufactured from hazelnut slurry (Ilyasoğlu et al. 2015). During storage, S. thermophilus showed a continuous decrease and at the end of storage, it was determined to be nearly $7 \log \mathrm{cfu} \mathrm{g}^{-1}$ for all yoghurt samples. The increase in the proportion of hazelnut beverage used in yoghurt production led to a rapid decrease in the number of S. thermophilus. However, no significant difference was detected between the $S$. thermophilus counts of the yoghurt samples at the end of storage ( $P>0.05)$. Bertolino et al. (2015) reported 1 log reduction in $S$. thermophilus viability in hazelnut skin added yogurt samples during storage. A slight decrease is also observed in nut fortified yoghurt samples after the $7^{\text {th }}$ day of storage (Ozturkoglu-Budak et al. 2016).
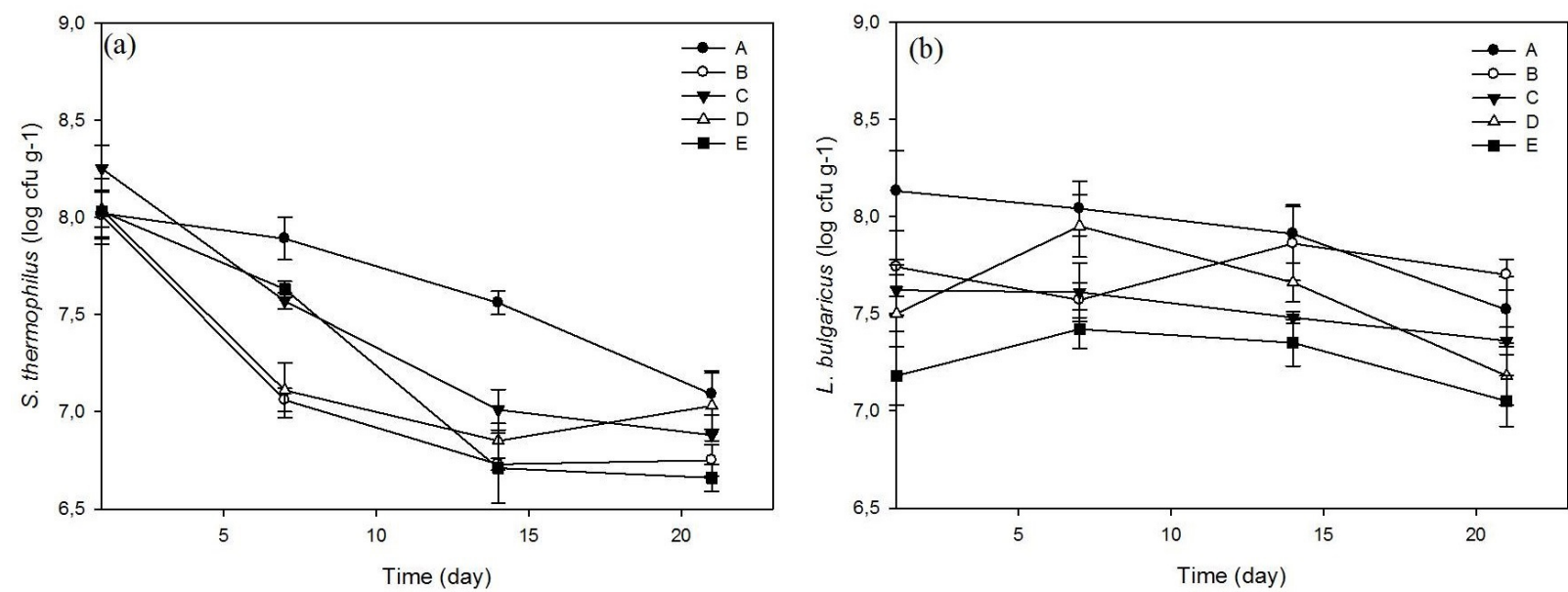

Figure 1. Growth of S. thermophilus (a) and L. delbrueckii subsp. bulgaricus (b) during storage of yoghurt-like products produced with cow milk and hazelnut beverage during storage at $4{ }^{\circ} \mathrm{C}$.

The highest number ( $8.13 \log \mathrm{cfu} \mathrm{g}^{-1}$ ) and the lowest number (7.18 log $\mathrm{cfu} \mathrm{g}^{-1}$ ) of L. bulgaricuss were found in $A$ and $E$ samples, respectively $(P<0.05)$. The use of hazelnut beverage in yoghurt production led to a decrease in the number of L. bulgaricus compared to the control (A) sample. The low L. bulgaricus counts in the samples produced with hazelnut beverage could be attributed to the inhibitory effect of antimicrobial and phenolic agents present in hazelnut (Oliveira et al. 2008). Bertolino et al. (2015) found the number of L. bulgaricus as $7.73 \operatorname{log~cfu~g}^{-1}$ in control and $7.64 \log \mathrm{cfu}$ $\mathrm{g}^{-1}$ in hazelnut skin enriched yogurt. Ilyasoğlu et al. (2015) reported that the number of $L$. bulgaricus obtained in yoghurt samples is 2.36 to $6.55 \mathrm{log} \mathrm{cfu} \mathrm{g}^{-1}$ which is lower than our findings. During storage, the number of L. bulgaricus in samples $A$ and $C$ decreased continuously. In samples $B$ and $E$, the 
number of L. bulgaricus increased until the $7^{\text {th }}$ day of storage and then decreased the rest of the storage. Generally, the number of L. bulgaricus counts (compared to day 1) was decreased at the end of storage except for sample D. Bertolino et al. (2015) found that the number of L. bulgaricus in yoghurt samples decreases less than 1 log throughout storage. Cell numbers of presumptive lactic acid bacteria in vegetable yogurt-like beverages decrease nearly 1 cycle after 30 days of storage period (Coda et al. 2012). Bernat et al. (2014) fermented hazelnut beverage with Lactobacillus rhamnosus GG and S. thermophilus and reported that defined formulation allows high probiotic survivals ( $10^{8} \mathrm{cfu}$ $\mathrm{mL}^{-1}$ ) throughout cold storage. No yeast-mold was detected throughout storage in any of the yoghurts analyzed.

\section{Water-holding capacity (WHC)}

The WHC of the yoghurt samples was presented in Table II. It was observed that control (sample A) showed the lowest value of WHC $(\mathrm{P}<0.05)$ and utilization of hazelnut beverage to yoghurt production led to an increase in WHC values of yoghurt probably due to the different types of proteins in cow milk and nut beverage. Interactions between proteins and water are very important for food systems due to their effects on the flavor and texture properties of yoghurt samples. There are several important factors influencing water holding capacity of foods. The amino acid composition of the proteins, the structures of the proteins and the ratio of surface polarity/hydrophobicity of the proteins are the major effects (Isanga \& Zhang 2009). The highest WHC was determined in sample E, which had a higher protein content $(P<0.05)$, and this might be due to effective immobilization of the aqueous phase by the nut protein in the yoghurt network, which thus significantly increased the WHC. Our results agree with the previous reports on WHC increase in yoghurt supplemented with dried nut (Ozturkoglu-Budak et al. 2016) and hazelnut slurry (Ilyasoğlu et al. 2015). The WHC of control sample significantly increased during storage, but the highest WHC was observed at sample $E$ at the end of the storage period. The increase of hazelnut beverage concentration for yoghurt production led to an increase in WHC values of yoghurt; however, there was no significant difference between samples $B$ and C (P>0.05). Ozturkoglu-Budak et al. (2016) reported that a slightly higher WHC observed in yoghurts fortified with dried nut towards the end of storage might be explained by the enriched protein content of fortified yogurts arising from nut composition.

\section{Rheological analysis}

The rheological properties of yoghurt samples during 21 days of storage were given in Table II. Ostwald de Waele model was successfully fitted to describe the flow behavior of the yoghurt samples (except sample E) with high $R^{2}$ values, ranging between 0.974 and 0.998 . We did not evaluate the flow curve of sample $E$ since the flow curve of this sample did not fit well to Ostwald de Waele model. All samples (except sample E) had a shear thinning behavior with values of flow behavior index ( $n$ ) ranging from 0.26 to 0.57 , with lower values for hazelnut beverage fortified yogurts compared to the control sample, suggesting a less viscous nature of the fortified product (Sah et al. 2016). Therefore, all yoghurts exhibited a shear thinning behavior which could be due to the shear-induced breakdown of the gel structure and the weakening of interactions within the yoghurt network structures. The consistency index $(K)$ value was observed to increase as the hazelnut beverage concentration increased throughout 
Table II. Water holding capacity (WHC) and rheological properties of yoghurt-like product produced with cow milk and hazelnut beverage during storage at $4^{\circ} \mathrm{C}$.

\begin{tabular}{|c|c|c|c|c|c|}
\hline & \multicolumn{5}{|c|}{ Storage time (days) } \\
\hline & Samples (v/v) & 1 & 7 & 14 & 21 \\
\hline \multirow{5}{*}{ WHC } & A & $52.86 \pm 2.24^{d D}$ & $56.49 \pm 0.56^{d C}$ & $60.07 \pm 2.43^{\mathrm{CB}}$ & $64.25 \pm 0.26^{\mathrm{CA}}$ \\
\hline & B & $58.05 \pm 0.14^{\mathrm{CB}}$ & $57.29 \pm 1.8^{\mathrm{cdB}}$ & $62.91 \pm 0.86^{\mathrm{bcA}}$ & $65.39 \pm 1.72^{C A}$ \\
\hline & $C$ & $59.71 \pm 2.06^{\mathrm{CB}}$ & $60.63 \pm 1.27^{\mathrm{bcB}}$ & $60.25 \pm 1.73^{\mathrm{CB}}$ & $64.85 \pm 1.89^{\mathrm{CA}}$ \\
\hline & D & $65.8 \pm 0.72^{\mathrm{bB}}$ & $62.82 \pm 2.25^{\mathrm{bB}}$ & $64.61 \pm 1.43^{\mathrm{bB}}$ & $69.16 \pm 0.73^{b A}$ \\
\hline & E & $72.33 \pm 1.66^{\mathrm{aA}}$ & $71.28 \pm 0.46^{\mathrm{aA}}$ & $72.93 \pm 1.29^{\mathrm{aA}}$ & $74.21 \pm 1.67^{\mathrm{aA}}$ \\
\hline \multirow{5}{*}{$\eta_{a p p}(P a . s)$} & A & $0.18 \pm 0.02^{\mathrm{CC}}$ & $0.38 \pm 0.06^{\mathrm{bA}}$ & $0.33 \pm 0.03^{C A B}$ & $0.28 \pm 0.01^{\mathrm{dB}}$ \\
\hline & B & $0.27 \pm 0.04^{\mathrm{bB}}$ & $0.45 \pm 0.02^{\mathrm{bA}}$ & $0.47 \pm 0.07^{\mathrm{bA}}$ & $0.52 \pm 0.06^{\mathrm{CA}}$ \\
\hline & C & $0.30 \pm 0.02^{b B}$ & $0.41 \pm 0.03^{\mathrm{bA}}$ & $0.45 \pm 0.02^{\mathrm{bA}}$ & $0.53 \pm 0.03^{C A}$ \\
\hline & $\mathrm{D}$ & $0.25 \pm 0.03^{b D}$ & $0.39 \pm 0.04^{b C}$ & $0.53 \pm 0.05^{b B}$ & $0.71 \pm 0.01^{\mathrm{bA}}$ \\
\hline & $E$ & $0.84 \pm 0.04^{\mathrm{aC}}$ & $1.27 \pm 0.28^{\mathrm{aB}}$ & $1.57 \pm 0.20^{\mathrm{aA}}$ & $1.54 \pm 0.11^{\mathrm{aA}}$ \\
\hline \multirow{5}{*}{$K\left(P a . s^{n}\right)$} & A & $2.04 \pm 0.18^{\mathrm{CB}}$ & $2.22 \pm 0.38^{\mathrm{CAB}}$ & $2.84 \pm 0.37^{\mathrm{CA}}$ & $1.63 \pm 0.22^{C B}$ \\
\hline & B & $5.07 \pm 0.52^{\mathrm{abB}}$ & $5.57 \pm 0.45^{b B}$ & $4.96 \pm 0.83^{b B}$ & $7.35 \pm 0.46^{\mathrm{bA}}$ \\
\hline & C & $4.77 \pm 0.39^{b B}$ & $4.97 \pm 0.21^{\mathrm{bB}}$ & $5.01 \pm 0.34^{b B}$ & $6.95 \pm 0.12^{\mathrm{bA}}$ \\
\hline & D & $5.94 \pm 0.48^{\mathrm{aC}}$ & $8.11 \pm 0.51^{\mathrm{aB}}$ & $11.02 \pm 0.26^{\mathrm{aA}}$ & $11.41 \pm 0.6^{\mathrm{aA}}$ \\
\hline & E & $N D^{* *}$ & ND & ND & ND \\
\hline \multirow{5}{*}{$n$} & $A$ & $0.40 \pm 0.04^{\mathrm{aB}}$ & $0.51 \pm 0.04^{\mathrm{aA}}$ & $0.49 \pm 0.03^{\mathrm{aAB}}$ & $0.57 \pm 0.08^{\mathrm{aA}}$ \\
\hline & B & $0.29 \pm 0.01^{b B}$ & $0.32 \pm 0.05^{b B}$ & $0.4 \pm 0.03^{b A}$ & $0.3 \pm 0.05^{b B}$ \\
\hline & C & $0.26 \pm 0.05^{\mathrm{bA}}$ & $0.33 \pm 0.02^{b A}$ & $0.32 \pm 0.03^{C A}$ & $0.25 \pm 0.03^{\mathrm{bA}}$ \\
\hline & $D$ & $0.28 \pm 0.05^{\mathrm{bA}}$ & $0.26 \pm 0.03^{\mathrm{bA}}$ & $0.25 \pm 0.06^{\mathrm{CA}}$ & $0.21 \pm 0.01^{\mathrm{CA}}$ \\
\hline & E & ND & ND & ND & ND \\
\hline \multirow{5}{*}{$R^{2}$} & $A$ & $0.998 \pm 0.01$ & $0.973 \pm 0.01$ & $0.996 \pm 0.01$ & $0.975 \pm 0.01$ \\
\hline & B & $0.998 \pm 0.01$ & $0.983 \pm 0.01$ & $0.994 \pm 0.01$ & $0.974 \pm 0.03$ \\
\hline & C & $0.998 \pm 0.01$ & $0.982 \pm 0.01$ & $0.993 \pm 0.01$ & $0.994 \pm 0.01$ \\
\hline & D & $0.993 \pm 0.01$ & $0.997 \pm 0.01$ & $0.988 \pm 0.01$ & $0.983 \pm 0.01$ \\
\hline & E & ND & ND & ND & ND \\
\hline
\end{tabular}

$a, b, c, d$ Means in the same column with different lowercase letters show significant differences between samples $(P<0.05)$. A, B, C, D Means in the same row with different uppercase letters show significant differences between storage periods $(P<0.05)$. napp: apparent viscosity at $50 \mathrm{~s}-1$ shear rate; $K$ : consistency index; $n$ : flow behavior index (dimensionless); $R^{2}$ : determination coefficient of Eq. 2. * The samples of $A$, $B, C, D$, and $E$ indicate a ratio of $1 / 0,3 / 1,2 / 1,1 / 1$ and $O / 1$ ( $v / v$, cow milk/hazelnut beverage), respectively. ** Not detected. 
the whole storage process. On the other hand, $K$ values of yoghurt samples (except sample $A$ ) significantly increased during fermentation period $(P<0.05)$. This could be related to occurring of flocculation in the hazelnut beverage fortified samples mainly due to a change in the $\mathrm{pH}$ and the effect of the water on the macromolecules and particles (Bernat et al. 2014). As can be seen in Table II, the viscosity values of the yoghurt samples varied considerably due to the proportion of milk types. In general, the viscosity values of the yoghurt samples are related to the total solid content and the higher total solid content leading to higher viscosity (Tamime \& Robinson 1999). Although the total solid contents of all yoghurt samples were almost similar, the lowest and the highest viscosity values were found as 0.18 and 0.84 Pa.s for sample A and E, respectively. This may partly be explained by the slightly higher protein contents in hazelnut beverage than those in cow's milk. The viscosity values of the yoghurts changed significantly during storage $(P<0.05)$. Up to the $7^{\text {th }}$ day of storage, an increase in the viscosity values was observed for all samples and then the viscosity value of sample A decreased. Nevertheless, the viscosity values of B, C, D and E samples increased during storage and this increase was probably due to more water-binding properties of the proteins in the added hazelnut beverage. Yaakob et al. (2012) reported that the protein present in coconut beverage formed more gel with the increase of acidity resulting in high viscosity of yoghurt. Similar findings were also observed for peanut beverage yoghurt (Isanga \& Zhang 2009).

\section{Color properties}

The color values of the yogurts produced using hazelnut beverage and cow milk were given in Table III. The $L^{*}$ values of yoghurt samples were measured between 82.64 and 92.07 at the initial of the storage period and the addition of hazelnut beverage to yoghurt resulted in a significant decrease in $L^{*}$ value $(P<0.05)$. In contrast to our findings, Ilyasoğlu et al. (2015) reported that the total solids content of the hazelnut slurry has no significant effect on the $L^{*}$ value of yoghurt-like product. Up to the $14^{\text {th }}$ day of storage, there was no statistical change in $L^{*}$ values of yoghurt samples (except for the sample $A$ ), but $L^{*}$ values of all samples increased at $21^{\text {st }}$ day days except sample $D$ which had no change during the storage period. All yoghurt samples had a negative $a^{*}$ value (except for sample E) and the usage of hazelnut beverage in yoghurt production caused an increase in redness of yoghurt samples $(P<0.05)$. Similarly, the usage of hazelnut beverage led to an increase in the $b^{*}$ values of the samples $(P<0.05)$. Ilyasoğlu et al. (2015) found that total solids content of the hazelnut slurry has a significant impact on the $a^{*}$ and $b^{*}$ values; enhances the $a^{*}$ and $b^{*}$ values, possibly due to the color properties of the hazelnut slurry. While not much change was observed in $a^{*}$ and $b^{*}$ values of sample $A$, they decreased in yoghurts containing hazelnut beverages during storage $(P<0.05)$. The highest and lowest $W I$ values were determined in samples $A$ and $E$, respectively $(P<0.05)$. Similar to $L^{*}$ values, the WI values decreased with the increase of hazelnut beverage concentration and increased during cold storage. The visual properties of whole milk are important characteristics for food preferences and the perception of milk whiteness has been demonstrated to have the most positive influence on increasing consumer appeal (García-Pérez et al. 2005). Although the replacement of cow milk with hazelnut beverage decreased the WI values of yoghurt samples compared to cow milk yoghurt, samples $B$ and $C$ could be acceptable considering WI value of sample $A$. 
Table III. Color properties of yoghurt-like product produced with cow milk and hazelnut beverage during storage at $4^{\circ} \mathrm{C}$.

\begin{tabular}{|c|c|c|c|c|c|}
\hline \multirow[b]{2}{*}{ Color Properties } & \multicolumn{5}{|c|}{ Storage time (days) } \\
\hline & Samples* & 1 & 7 & 14 & 21 \\
\hline \multirow{5}{*}{$L^{*}$ value } & A & $92.07 \pm 0.16^{\mathrm{aC}}$ & $92.20 \pm 0.02^{\mathrm{aBC}}$ & $92.28 \pm 0.12^{\mathrm{aAB}}$ & $92.43 \pm 0.09^{\mathrm{aA}}$ \\
\hline & $B$ & $89.86 \pm 0.06^{\mathrm{bB}}$ & $89.85 \pm 0.27^{\mathrm{bB}}$ & $89.86 \pm 0.21^{\mathrm{bB}}$ & $90.60 \pm 0.18^{b A}$ \\
\hline & C & $88.98 \pm 0.04^{\mathrm{CB}}$ & $89.10 \pm 0.04^{c B}$ & $89.14 \pm 0.06^{\mathrm{CAB}}$ & $89.41 \pm 0.29^{C A}$ \\
\hline & D & $87.12 \pm 0.01^{\mathrm{dA}}$ & $87.09 \pm 0.03^{d A}$ & $87.17 \pm 0.16^{d A}$ & $87.15 \pm 0.21^{\mathrm{dA}}$ \\
\hline & $E$ & $82.64 \pm 0.01^{e B}$ & $82.85 \pm 0.04^{\mathrm{eAB}}$ & $82.89 \pm 0.24^{\mathrm{eAB}}$ & $83.08 \pm 0.11^{\mathrm{eA}}$ \\
\hline \multirow{5}{*}{$a^{*}$ value } & A & $-1.19 \pm 0.01^{e A}$ & $-1.2 \pm 0.08^{\mathrm{eA}}$ & $-1.25 \pm 0.06^{\mathrm{eA}}$ & $-1.2 \pm 0.6^{\mathrm{eA}}$ \\
\hline & B & $-0.59 \pm 0.03^{d A B}$ & $-0.52 \pm 0.05^{d A}$ & $-0.67 \pm 0.1^{d B}$ & $-0.92 \pm 0.01 \mathrm{dC}$ \\
\hline & C & $-0.24 \pm 0.02^{C A}$ & $-0.28 \pm 0.01^{C A B}$ & $-0.36 \pm 0.02^{C B C}$ & $-0.4 \pm 0.09^{c C}$ \\
\hline & D & $-0.13 \pm 0.01^{b A}$ & $-0.09 \pm 0.02^{b A}$ & $-0.17 \pm 0.03^{b A}$ & $-0.19 \pm 0.09^{b A}$ \\
\hline & $E$ & $0.48 \pm 0.01^{\mathrm{aA}}$ & $0.44 \pm 0.02^{\mathrm{AAB}}$ & $0.41 \pm 0.03^{a B}$ & $0.38 \pm 0.01^{\mathrm{aB}}$ \\
\hline \multirow{5}{*}{$b^{*}$ value } & A & $11.22 \pm 0.07^{\mathrm{dA}}$ & $11.29 \pm 0.08^{\mathrm{CA}}$ & $11.27 \pm 0.11^{\mathrm{CA}}$ & $11.25 \pm 0.02^{\mathrm{CA}}$ \\
\hline & $\mathrm{B}$ & $11.25 \pm 0.02^{\mathrm{dA}}$ & $11.25 \pm 0.06^{\mathrm{CA}}$ & $11.06 \pm 0.07^{\mathrm{CB}}$ & $11.12 \pm 0.13^{C A B}$ \\
\hline & C & $11.74 \pm 0.01^{\mathrm{CA}}$ & $11.68 \pm 0.05^{\mathrm{bA}}$ & $11.63 \pm 0.03^{\mathrm{bA}}$ & $11.48 \pm 0.14^{\mathrm{bB}}$ \\
\hline & $D$ & $11.96 \pm 0.03^{\mathrm{bA}}$ & $11.75 \pm 0.04^{b B}$ & $11.72 \pm 0.07^{\mathrm{bB}}$ & $11.55 \pm 0.06^{b c}$ \\
\hline & E & $12.68 \pm 0.05^{\mathrm{aA}}$ & $12.32 \pm 0.03^{\mathrm{aB}}$ & $12.23 \pm 0.04^{\mathrm{aC}}$ & $12.24 \pm 0.04^{\mathrm{aC}}$ \\
\hline \multirow{5}{*}{ WI } & A & $85.89 \pm 0.15^{\mathrm{bA}}$ & $86.23 \pm 0.24^{\mathrm{aA}}$ & $86.28 \pm 0.07^{\mathrm{aA}}$ & $86.38 \pm 0.01^{\mathrm{aA}}$ \\
\hline & $B$ & $84.84 \pm 0.05^{C B}$ & $84.84 \pm 0.19^{b c B}$ & $85.09 \pm 0.09^{b B}$ & $85.41 \pm 0.21^{\mathrm{aB}}$ \\
\hline & $C$ & $84.39 \pm 0.02^{b c}$ & $84.45 \pm 0.05^{b c}$ & $84.59 \pm 0.06^{\mathrm{abc}}$ & $84.81 \pm 0.3^{\mathrm{aC}}$ \\
\hline & $\mathrm{D}$ & $82.42 \pm 0.03^{b D}$ & $82.68 \pm 0.01^{\mathrm{abD}}$ & $82.82 \pm 0.24^{a b D}$ & $82.57 \pm 0.19^{\mathrm{aD}}$ \\
\hline & E & $78.49 \pm 0.03^{\mathrm{bE}}$ & $78.87 \pm 0.05^{\mathrm{aE}}$ & $78.96 \pm 0.27^{\mathrm{aE}}$ & $79.11 \pm 0.11^{\mathrm{aE}}$ \\
\hline
\end{tabular}

$a, b, c, d, e$ Means in the same column with different lowercase letters show significant differences between samples $(P<0.05)$. A, B, C, D, E Means in the same row with different uppercase letters show significant differences between storage periods $(P<0.05)$. $L^{*}$ : lightness; $a^{*}$ : red-green; $b^{*}$ : yellow-blue; WI: whiteness index. ${ }^{*}$ The samples of $A, B, C, D$, and $E$ indicate a ratio of $1 / 0,3 / 1,2 / 1,1 / 1$ and $O / 1$ ( $v / v$, cow milk/hazelnut beverage), respectively.

\section{Phenolic compounds and antioxidant activity}

The bioactive properties of yoghurts produced from a blend of cow and hazelnut beverage during storage were given in Table IV. In the yoghurt samples, total phenolic content (TPC) was determined between 94.48 and $264.8 \mathrm{GAE} \mu \mathrm{g} \mathrm{g}^{-1}$ on the first day of storage. As expected, the TPC value in yogurt produced with hazelnut beverage was higher than the others $(P<0.05)$ and the use of hazelnut beverage in yoghurt production led to an increase in the TPC of samples $(P<0.05)$. This increase is in accordance with the results obtained by Ilyasoğlu et al. (2015) for yoghurt-like product manufactured from hazelnut slurry and Bertolino et al. (2015) for yoghurt fortified different hazelnut skins. Hazelnut 
is generally recognized as a good source of several required food nutrients, including many kinds of polyphenols with the main types being tocopherols, especially $\alpha$ - and $\gamma$-tocopherols, gallic acid, p-hydroxybenzoic acid, epicatechin, sinapic acid, and quercetin (Ozturkoglu-Budak et al. 2016). During storage, TPC tended to increase in yoghurt samples $(P<0.05)$. The increase in TPC throughout storage is also observed for kefir-fermented soy beverages and hazelnut skin added yoghurt samples (Bertolino et al. 2015, da Silva Fernandes et al. 2017). Acidic pH of yoghurt samples is also an advantage that could induce the hydrolysis of some phenolic compounds bonded to other food components (da Silva Fernandes et al. 2017). As shown in Table IV, the lowest and highest antioxidant capacity of yoghurt samples was found as $3.22 \mu \mathrm{M}$ Trolox $g^{-1}$ and $15.37 \mu \mathrm{M}$ Trolox $g^{-1}$ in samples $A$ and $E$, respectively $(P<0.05)$. Antioxidant capacity increased with the addition of hazelnut beverage $(P<0.05)$ that is compatible with TPC values of yoghurt samples. McCue \& Shetty (2005) reported that increased antioxidant activities during soy beverage yogurt production using kefir cultures may be due to mobilization of phenolic contents. Luana et al. (2014) reported that the yoghurt samples enriched with oatmeal had higher levels of antioxidant capacity than control samples. The antioxidant activity of yoghurt samples except samples B and $C$ increased until the $7^{\text {th }}$ day of storage and then showed a downward trend for all samples. Tea supplemented yoghurt samples showed a similar tendency as our findings during the storage period (Najgebauer-Lejko et al. 2011). The antioxidant capacity of grape seed extract fortified yoghurt also decreased throughout storage and the degradation of polyphenols and decrement of yoghurts antioxidant activities followed first-order kinetic (Chouchouli et al. 2013).

Table IV. Bioactive properties of yoghurt-like product produced with cow milk and hazelnut beverage during storage at $4^{\circ} \mathrm{C}$.

\begin{tabular}{|c|c|c|c|c|c|}
\hline & \multicolumn{5}{|c|}{ Storage time (days) } \\
\hline Bioactive Properties & Samples & 1 & 7 & 14 & 21 \\
\hline \multirow{5}{*}{$\operatorname{TPC}\left(\mathrm{GAE} \mu \mathrm{g}^{-1}\right)$} & $A$ & $94.48 \pm 1.5^{e B}$ & $96.82 \pm 1.51^{e B}$ & $101.96 \pm 1.3^{\mathrm{eA}}$ & $102 \pm 1.3^{\mathrm{eA}}$ \\
\hline & B & $130.51 \pm 3.2^{\mathrm{dB}}$ & $133 \pm 4.06^{\mathrm{dB}}$ & $141.49 \pm 2.52^{\mathrm{dA}}$ & $144.21 \pm 1.22^{\mathrm{dA}}$ \\
\hline & C & $144.09 \pm 1.31^{\mathrm{CBC}}$ & $143.59 \pm 2.68^{\mathrm{cC}}$ & $148.62 \pm 0.99^{C A}$ & $148.29 \pm 1.71^{\mathrm{CA}}$ \\
\hline & $\mathrm{D}$ & $161.56 \pm 0.52^{b B}$ & $168.05 \pm 0.6^{\mathrm{bA}}$ & $168.57 \pm 0.15^{\mathrm{bA}}$ & $169.51 \pm 0.96^{\mathrm{bA}}$ \\
\hline & $E$ & $264.8 \pm 1.44^{\mathrm{aB}}$ & $271.08 \pm 1.43^{\mathrm{aA}}$ & $268.16 \pm 2.01^{\mathrm{aA}}$ & $257.18 \pm 1.51^{\mathrm{aC}}$ \\
\hline \multirow{5}{*}{$\mathrm{DPPH}\left(\mu \mathrm{M}\right.$ Trolox $\left.\mathrm{g}^{-1}\right)$} & A & $3.22 \pm 0.36^{\mathrm{eB}}$ & $4.35 \pm 0.42^{\mathrm{eA}}$ & $2.96 \pm 0.6^{\mathrm{eBC}}$ & $2.35 \pm 0.17^{\mathrm{eC}}$ \\
\hline & $\mathrm{B}$ & $6.99 \pm 0.33^{\mathrm{dA}}$ & $6.13 \pm 0.28^{\mathrm{dB}}$ & $5.52 \pm 0.49^{\mathrm{dBC}}$ & $4.98 \pm 0.29^{d C}$ \\
\hline & C & $7.75 \pm 0.09^{C A}$ & $7.68 \pm 0.33^{C A}$ & $6.45 \pm 0.13^{C B}$ & $6.61 \pm 0.18^{\mathrm{CB}}$ \\
\hline & $\mathrm{D}$ & $8.75 \pm 0.24^{b B}$ & $9.43 \pm 0.62^{\mathrm{bA}}$ & $8.56 \pm 0.27^{\mathrm{bBC}}$ & $7.91 \pm 0.09^{b c}$ \\
\hline & $E$ & $15.37 \pm 0.28^{\mathrm{aA}}$ & $15.42 \pm 0.4^{\mathrm{aA}}$ & $13.23 \pm 0.41^{\mathrm{aB}}$ & $12.94 \pm 0.82^{\mathrm{aB}}$ \\
\hline
\end{tabular}

a, b, c, d, e Means in the same column with different lowercase letters show significant 667 differences between samples $(P<0.05)$. A, B, C Means in the same row with different uppercase letters show significant differences 669 between storage periods ( $P<0.05$ ). TPC: total phenolic content; GAE: gallic acid equivalent; DPPH: 1,1-diphenyl-2-671 picrylhydrazil. * The samples of $A, B, C, D$, and $E$ indicate a ratio of $1 / 0,3 / 1,2 / 1,1 / 1$ and $0 / 1(v / v$, cow milk/ hazelnut beverage), respectively. 


\section{Organic acid profile}

The organic acid content of yoghurts produced using cow milk and hazelnut beverage and the variation throughout storage was given in Fig. 2. The highest lactic acid $\left(10.31 \mathrm{mg} \mathrm{g}^{-1}\right)$ after fermentation was detected in sample A (Fig. 2a). The lactic acid production decreased in an inverse proportion with the increase of the added hazelnut beverage concentration. The lowest lactic acid was determined in sample $\mathrm{E}$ (6.84 $\left.\mathrm{mg} \mathrm{g}^{-1} ; \mathrm{P}<0.05\right)$. Bertolino et al. (2015) reported that the addition of hazelnuts in yoghurt production results in lower lactic acid levels and decreases acid production. Lactic acid levels in yogurt increased during storage, with a minimal increase in sample $E(P<0.05)$. The amounts of acetic acid in the yoghurt samples on the first day were determined as $0.09-0.13 \mathrm{mg} \mathrm{g}^{-1}$ and there was no statistically significant difference between the samples (P>0.05; Fig. 2b). However, yoghurt produced by adding hazelnut beverage had higher acetic acid content. An increase in the acetic acid content of the samples during storage was observed. The maximum increase was observed in sample A, while the minimum change was determined in sample $E$. At the end of fermentation, the citric acid level was found between 0.63 and $2.07 \mathrm{mg} \mathrm{g}^{-1}$ in yoghurt samples and the highest and the lowest value belongs to the sample of $A$ and $E$, respectively (Fig. 2C). The decrease in the amount of citric acid was determined depending on the concentration of hazelnut beverage added to yoghurt $(P<0.05)$. The content of citric acid did not change during storage and this was probably related to the yoghurt culture which did not use citrate (Bertolino et al. 2015, Adhikari et al. 2002). As can be seen in Fig. $2 \mathrm{~d}$, malic acid was not detected in the yogurts produced only with cow's milk (found below the limit) but it was found between $0.11-0.64 \mathrm{mg} \mathrm{g}^{-1}$ in the yogurts with hazelnut beverage. The increase in the amount of malic acid in yogurts was related to the ratio of hazelnut beverage and the highest value was found in sample E. Similar results were obtained in yoghurt samples with hazelnut skin (Bertolino et al. 2015). Succinic acid values determined in yoghurt samples ranged from 0.41 to $0.76 \mathrm{mg} \mathrm{g}^{-1}$ (Fig. 2e). The highest succinic acid content was detected in sample B, while the lowest in sample E. During storage, the succinic acid contents of the samples were not significantly changed $(P>0.05)$.

\section{Fatty acid profile}

The change in the fatty acid profiles of yoghurt samples produced using cow's milk and hazelnut beverage during storage was given in Table $V$. As it can be seen from the table, the fatty acids that are dominant in yoghurt samples produced using cow milk were myristic, palmitic, stearic and oleic acid. However, in yoghurt samples produced using only hazelnut beverage, dominant fatty acids were palmitic, oleic and linoleic. As expected, the increase in the ratio of hazelnut beverage used in yoghurt production also changed the fatty acid profile. Particularly, saturated fatty acids such as myristic, palmitic and stearic decreased and unsaturated fatty acids such as oleic and linoleic increased depending on the ratio of hazelnut beverage. In accordance with the previous studies (Ozturkoglu-Budak et al. 2016, Amaral et al. 2005) and the sample E in this study, hazelnut was identified as a significant source of monounsaturated fatty acids with higher contents of oleic acids-the main group of fatty acids- and also polyunsaturated fatty acids with higher linoleic acid. Palmitic acid, the most abundant fatty acid of cow's milk ranged from $28.17 \%$ to $28.43 \%$ in control sample during storage. Oleic acid was the highest in the yogurts produced using hazelnut beverage and showed a decrease from $74.77 \%$ to $70.44 \%$ in sample $E$ during storage. Oleic acid is also dominant fatty 

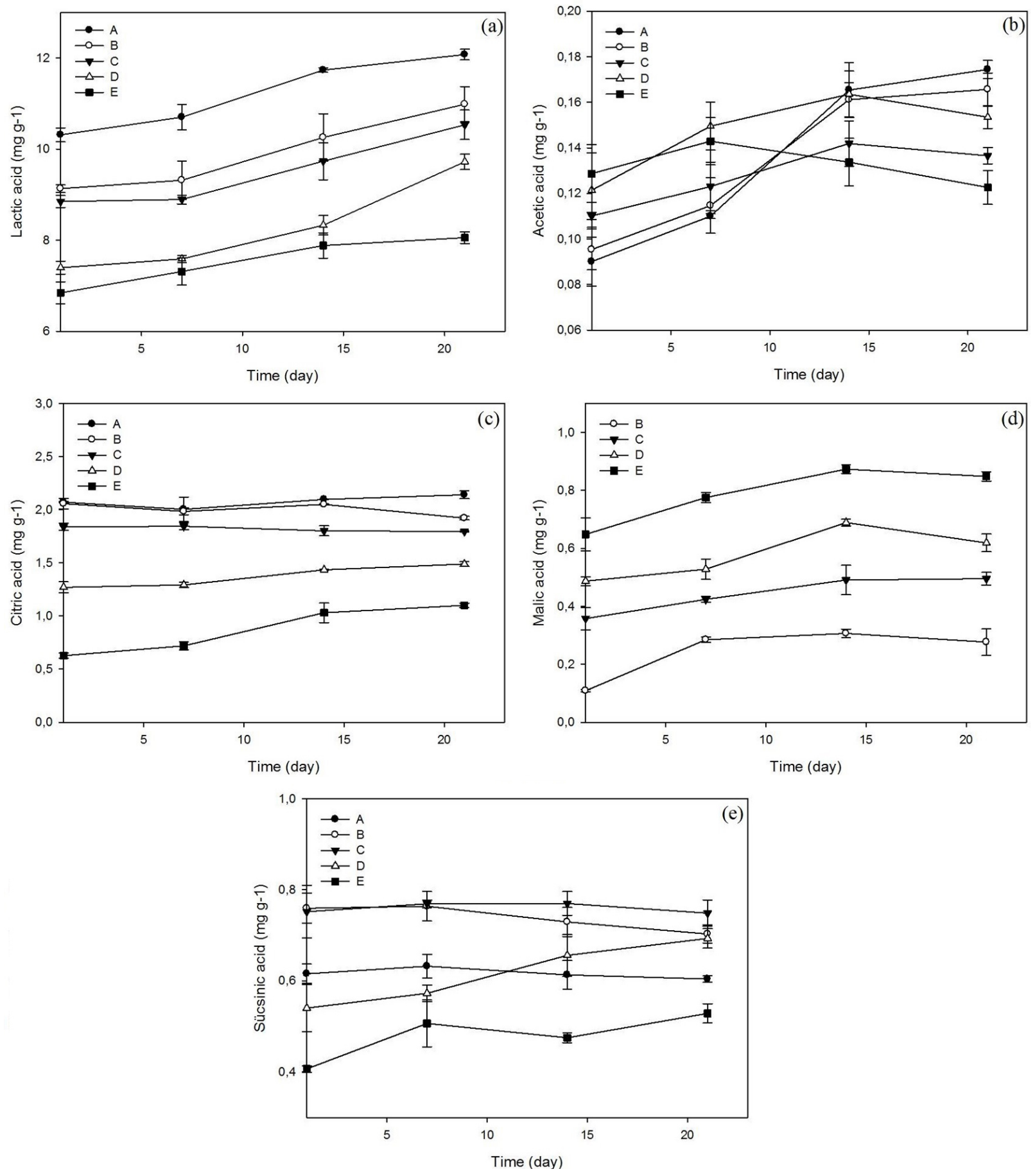

Figure 2. Organic acid profiles of yoghurt-like product produced with cow milk and hazelnut beverage during storage at $4^{\circ} \mathrm{C}$. (a) lactic acid, (b) acetic acid, (c) citric acid, (d) malic acid, (e) sücsinic acid. 


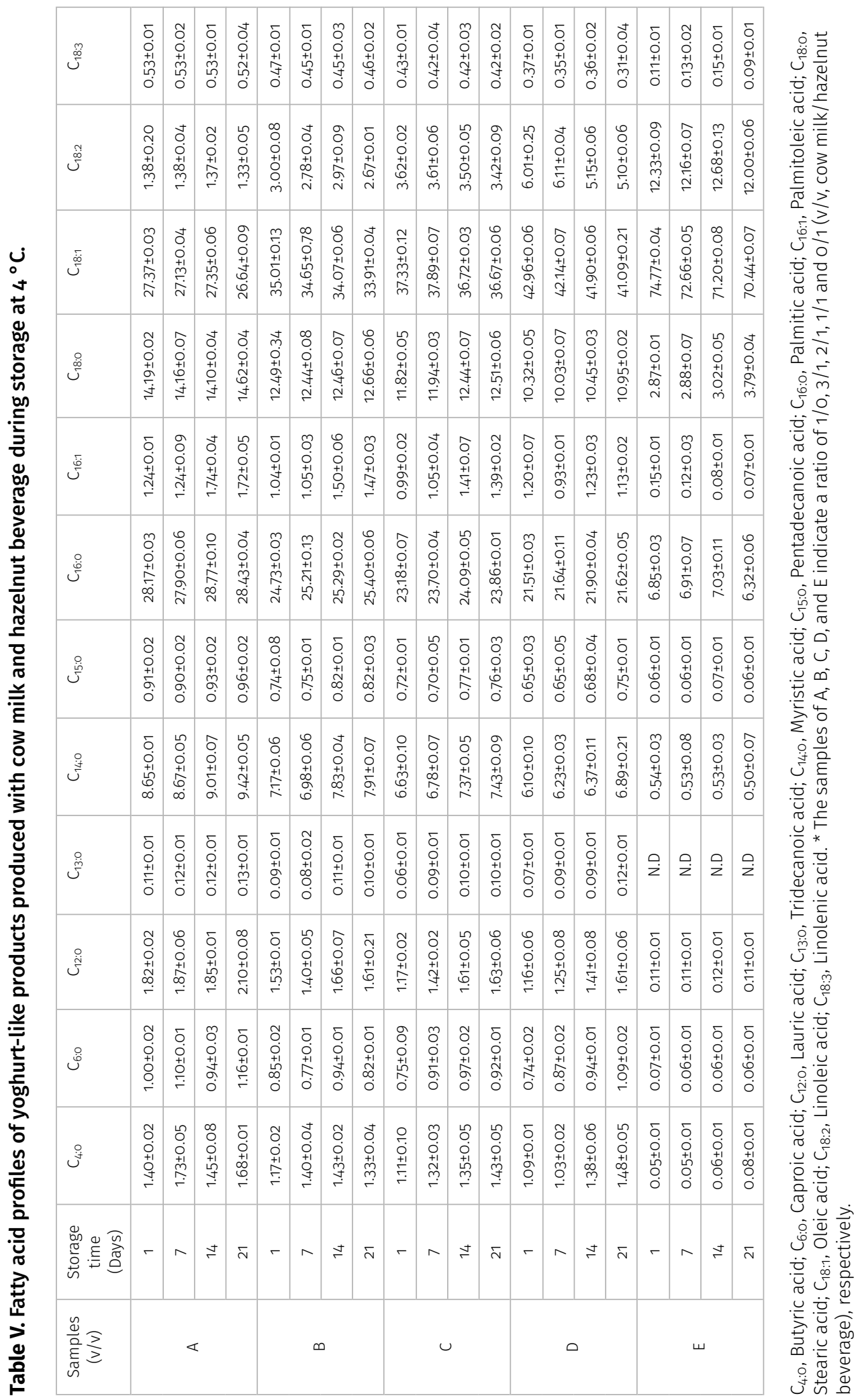



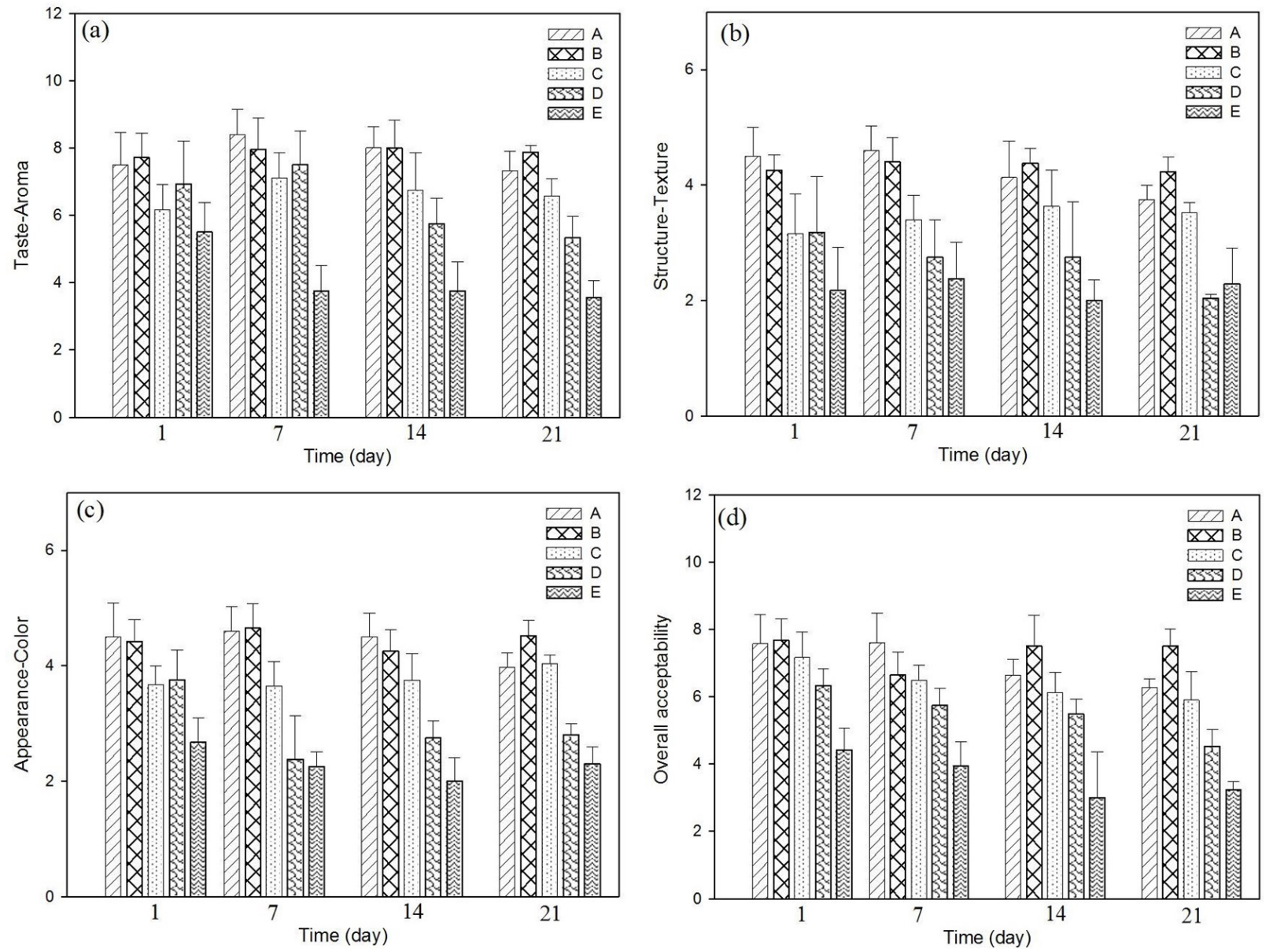

Figure 3. Sensory evaluation of yoghurt-like products produced with cow milk and hazelnut beverage during storage at $4^{\circ} \mathrm{C}$. (a) Taste-aroma, (b) structure-texture, (c) appearance-color, (d) overall acceptability.

acid in yoghurt-like product manufactured from hazelnut slurry as $84-85 \mathrm{~g} 100 \mathrm{~g}^{-1}$ sample (Ilyasoğlu et al. 2015). The replacement of saturated fatty acids with unsaturated fatty acids like oleic and linoleic acids leads to increased high-density lipoprotein cholesterol and decreased low-density lipoprotein cholesterol, triacylglycerol, lipid oxidation, and low-density lipoprotein susceptibility to oxidation (Yu-Poth et al. 2000). During storage, ratios of oleic, linoleic and linolenic of unsaturated fatty acids reduced in all samples, but palmitoleic acid ratio did not change much, except for sample E., lauric, myristic, pentadecanoic and palmitic acid ratios increased in yoghurt samples, except for sample E.

\section{Sensory properties}

The sensory ratings of individual products during the storage period were shown in Fig. 3. The addition of hazelnut beverage reduced the taste-aroma values of yoghurt samples (Fig. 3a). Yoghurt, specially produced from only hazelnut beverage, was not liked by the panelists in terms of taste-aroma. Panelists pointed out that sample $\mathrm{E}$ had a taste that was far from the characteristic taste of yogurt. However, the yoghurt sample produced with a mixture of cow and hazelnut beverage $(3 / 1, v / v)$ got a high score on both 1 and 21 days of storage. The taste-aroma scores of samples $D$ and $E$ decreased 
during storage $(P<0.05)$ and no significant change was detected in the other samples $(P>0.05)$. The structure-texture scores of the yoghurt samples determined by the panelists are given in Fig. 3b. The highest score was given to the yogurts produced from only cow's milk while the lowest score was given to the samples with only hazelnut beverage. The addition of hazelnut beverage in yoghurt production decreased the structure-texture scores of all samples $(P<0.05)$. The reason for this is probably the phase separation occurrence before the yoghurt gel is formed in the fermentation stage. However, the structure-texture results of sample $B$ were similar to the control sample $(P>0.05)$. At the end of the storage period, the B sample was more appreciated than the control sample in terms of structure. The appearance-color scores of the yoghurt samples are shown in Fig. 3c. The highest score was obtained for sample A and the lowest score for sample E. Instrumental color analysis revealed that the hazelnut beverage color was darker than that of the cow's and therefore, the increase in hazelnut beverage concentration used in yoghurt production caused a darker color. The overall acceptability scores of yoghurt samples were given in Fig. 3d. The use of hazelnut beverage in yoghurt production led to a decrease in the overall acceptability score of the product. Panelists pointed out that the yoghurts produced with hazelnut beverage had a dense gel structure that does not reflect the characteristic yogurt body. Therefore, it can be concluded that the yogurt produced from only hazelnut beverage was not acceptable. However, the mixture of cow milk and hazelnut beverage at a ratio of $3 / 1(\mathrm{v} / \mathrm{v})$ resulted in a product with higher overall acceptability than the control sample.

\section{CONCLUSION}

This study demonstrated that hazelnut beverage can be utilized as an alternative source of antioxidants and unsaturated fatty acids to fortify yogurt. Yogurt fortified with hazelnut beverage provides higher viscosity and lower syneresis compared to cow's milk yoghurt. Yoghurt with hazelnut beverage had lower acidity values throughout storage, which is of great significance to expand shelf life. Microorganism counts of all yoghurt samples were found higher than recommended levels in Codex Alimentarius $\left(10^{7} \mathrm{cfu}^{-1}\right)$ during storage. Antioxidant capacity and total phenolic compounds increased with the addition of hazelnut beverage concentration. Yoghurts with hazelnut beverage can be considered to have more health-promoting properties than cow's milk yoghurt in terms of bioactive properties. Sensory evaluation revealed that the increase in hazelnut beverage concentration decreased the sensory scores. However, in terms of physicochemical and overall sensory acceptability results, the ratio of 3 to 1 (cow milk/hazelnut beverage, $v / v$ ) is recommended for the best yoghurt production.

\section{Acknowledgments}

The authors acknowledge financial support provided by Turkish Scientific and Technical Research Council of Turkey for the project (Project Number: TOVAG 1140174). 


\section{REFERENCES}

ABOULFAZLI F \& BABA AS. 2015. Effect of vegetable milk on survival of probiotics in fermented ice cream under gastrointestinal conditions. Food Sci Technol 21(3): 391-397. doi:10.3136/fstr.21.391.

ADHIKARI K, GRUW IU, MUSTAPHA A \& FERNANDO LN. 2002. Changes of the Profile of Organic Acids in Plain Set and Stirred Yoghurts During Manufacture and Refrigerated Storage. J Food Qual 25: 435-451.

ALFARO SANABRIA LA. 2012. Development of a frozen yogurt fortified with a nano-emulsion containing purple rice bran oil. Ph.D. thesis. Louisiana State University.

AMARAL JS, CASAL S, CITOVÁ I, SANTOS A, SEABRA RM \& OLIVEIRA BPP. 2005. Characterization of several hazelnut (Corylus avellana L.) cultivars based in chemical, fatty acid and sterol composition. Eur Food Res Technol 222(3-4): 274-280. doi:10.1007/s00217-005-0068-0.

AOAC - ASSOCIATION OF OFFICIAL ANALYTICAL CHEMISTS. 1995. Official Methods of Analysis. 16th ed, Washington DC.

ATALAR I. 2019. Functional kefir production from high pressure homogenized hazelnut milk. LWT - Food Sci Technol 107: 256-263. doi:10.1016/j.lwt.2019.03.013.

BERNAT N, CHÁFER M, CHIRALT A \& GONZÁLEZ-MARTINEZ C. 2014. Hazelnut milk fermentation using probiotic Lactobacillus rhamnosus GG and inulin. Int Food Sci Technol 49(12): 2553-2562. doi:10.1111/ijfs.12585.

BERTOLINO M, BELVISO S, DAL BELLO B, GHIRARDELLO D, GIORDANO M, ROLLE L, GERBI V \& ZEPPA G. 2015. Influence of the addition of different hazelnut skins on the physicochemical, antioxidant, polyphenol and sensory properties of Â yogurt. LWT - Food Sci Technol 63(2): 1145-1154. doi:10.1016/j.lwt.2015.03.113.

BRADLEY R, ARNOLD E, BARBANO D, SEMERAD R, SMITH D \& VINES B. 1992. Chemical and physical methods. In: Standard Methods for the Examination of Dairy Products. p. 433-529. Washington, DC: American Public Health Association.

CHOUCHOULI V, KALOGEROPOULOS N, KONTELES SJ, KARVELA E, MAKRIS DP \& KARATHANOS VT. 2013. Fortification of yoghurts with grape (Vitis vinifera) seed extracts. LWT - Food Sci Technol 53(2): 522-529. doi:10.1016/j.lwt.2013.03.008.

CODA R, LANERA A, TRANI A, GOBBETTI M \& DI CAGNO R. 2012. Yogurt-like beverages made of a mixture of cereals, soy and grape must: microbiology, texture, nutritional and sensory properties. Int J Food Microbiol 155(3):
120-127. doi:10.1016/j.ijfoodmicro.2012.01.016. URL http:/ / www.ncbi.nlm.nih.gov/pubmed/22341935.

DA SILVA FERNANDES M, SANCHES LIMA F, RODRIGUES D, HANDA C, GUELFI M, GARCIA S \& IDA EI. 2017. Evaluation of the isoflavone and total phenolic contents of kefir-fermented soymilk storage and after the in vitro digestive system simulation. Food Chem 229: 373-380. doi:10.1016/j.foodchem.2017.02.095.

DEMIRCI T, AKTAŞ K, SÖZERI D, ÖZTURK HI \& AKIN N. 2017. Rice bran improve probiotic viability in yoghurt and provide added antioxidative benefits. J Funct Foods 36: 396-403. doi:10.1016/j.jff.2017.07.019.

DERVISOGLU M, GUL O, GUVENC D, YAZICI F, ATMACA $E$ \& AKSOY A. 2013. Evaluation of Chemical and Microbiological Characteristics and Fatty Acid Profiles of Butter Samples Collected from the Black Sea Region of Turkey. Asian J Chem 25(18): 10185-10190. doi:10.14233/ajchem.2013.15222.

DONKOR O, HENRIKSSON A, VASILJEVIC T \& SHAH N. 2007. Rheological properties and sensory characteristics of set-type yoy yogurt. J Agric Food Chem 55(24): 9868-9876. doi:10.1021/jf071050r.

FARNWORTH ER, MAINVILLE I, DESJARDINS MP, GARDNER N, FLISS I \& CHAMPAGNE C. 2007. Growth of probiotic bacteria and bifidobacteria in a soy yogurt formulation. Int J Food Microbiol 116(1): 174-181. doi:10.1016/j.ijfoodmicro.2006.12.015. URL http:/ / www.ncbi.nlm.nih.gov/pubmed/17292991.

GARCÍA-PÉREZ FJ, LARIO Y, FERNÁNDEZ-LÓPEZ J, SAYAS E, PÉREZ-ALVAREZ JA \& SENDRA E. 2005. Effect of orange fiber addition on yogurt color during fermentation and cold storage. Color Res Appl 30(6): 457-463. doi:10.1002/col.20158.

GHORBANZADE T, JAFARI SM, AKHAVAN S \& HADAVI R. 2017. Nano-encapsulation of fish oil in nano-liposomes and its application in fortification of yogurt. Food Chem 216: 146-152. doi:10.1016/j.foodchem.2016.08.022. URL http:// www.ncbi.nlm.nih.gov/pubmed/27596403.

GUL O, ATALAR I, MORTAS M, SARICAOGLU FT \& YAZICI F. 2018. Application of TOPSIS methodology to determine optimum hazelnut cake concentration and high pressure homogenization condition for hazelnut milk production based on physicochemical, structural and sensory properties. J Food Meas Charact 12(4): 2404-2415. doi:10.1007/s11694-018-9857-6.

GUL O, MORTAS M, ATALAR I, DERVISOGLU $M$ \& KAHYAOGLU T. 2015. Manufacture and characterization of kefir made from cow and buffalo milk, using kefir grain and starter culture. J Dairy Sci 
98(3): 1517-1525. doi:10.3168/jds.2014-8755. URL http://www.ncbi.nlm.nih.gov/pubmed/25582588.

GUL O, SARICAOGLU FT, MORTAS M, ATALAR I \& YAZICI F. 2017. Effect of high pressure homogenization (HPH) on microstructure and rheological properties of hazelnut milk. Innov Food Sci Emerg Technol 41: 411-420. doi:10.1016/j.ifset.2017.05.002.

ILYASOĞLU H, YILMAZ F, BURNAZ NA \& BALTACI C. 2015. Preliminary assessment of a yoghurt-like product manufactured from hazelnut slurry: Study using response surface methodology. LWT - Food Sci Technol 62(1): 497-505. doi:10.1016/j.lwt.2014.06.023.

ISANGA J \& ZHANG G. 2009. Production and evaluation of some physicochemical parameters of peanut milk yoghurt. LWT - Food Sci Technol 42(6): 1132-1138. doi:10.1016/j.lwt.2009.01.014.

KUMAR P \& MISHRA H. 2004. Mango soy fortified set yoghurt: effect of stabilizer addition on physicochemical, sensory and textural properties. Food Chem 87(4): 501-507. doi:10.1016/j.foodchem.2003.12.022.

LUANA N, ROSSANA C, CURIEL JA, KAISA P, MARCO G \& RIZZELLO CG. 2014. Manufacture and characterization of a yogurt-like beverage made with oat flakes fermented by selected lactic acid bacteria. Int J Food Microbiol 185: 17-26. doi:10.1016/j.ijfoodmicro.2014.05.004. URL http:// www.ncbi.nlm.nih.gov/pubmed/24929680.

MALEKI N, KHODAIYAN F \& MOUSAVI SM. 2015. Antioxidant activity of fermented Hazelnut milk. Food Sci Biotechnol 24(1): 107-115. doi:10.1007/s10068-015-0016-0.

MCCUE PP \& SHETTY K. 2005. Phenolic antioxidant mobilization during yogurt production from soymilk using Kefir cultures. Process Biochem 40(5): 1791-1797. doi:10.1016/j.procbio.2004.06.067.

NAJGEBAUER-LEJKO D, SADY M, GREGA T \& WALCZYCKA M. 2011. The impact of tea supplementation on microflora, pH and antioxidant capacity of yoghurt. Int Dairy J 21(8): 568-574. doi:10.1016/j.idairyj.2011.03.003.

OLIVEIRA I, SOUSA A, MORAIS JS, FERREIRA IC, BENTO A, ESTEVINHO L \& PEREIRA JA. 2008. Chemical composition, and antioxidant and antimicrobial activities of three hazelnut (Corylus avellana L.) cultivars. Food Chem Toxicol 46(5): 1801-1807. doi:10.1016/j.fct.2008.01.026. URL http://www.ncbi.nlm.nih.gov/pubmed/18316150.

OZTURKOGLU-BUDAK S, AKAL C \& YETISEMIYEN A. 2016. Effect of dried nut fortification on functional, physicochemical, textural, and microbiological properties of yogurt. J Dairy Sci 99(11): 8511-8523. doi:10.3168/jds.2016-11217. URL http://www.ncbi.nlm.nih. gov/pubmed/27638255.

SAH BNP, VASILJEVIC T, MCKECHNIE S \& DONKOR ON. 2016. Physicochemical, textural and rheological properties of probiotic yogurt fortified with fibre-rich pineapple peel powder during refrigerated storage. LWT - Food Sci Technol 65: 978-986. doi:10.1016/j.lwt.2015.09.027.

SANTOS CC, LIBECK BDA S \& SCHWAN RF. 2014. Co-culture fermentation of peanut-soy milk for the development of a novel functional beverage. Int I Food Microbiol 186: 32-41. doi:10.1016/j.ijfoodmicro.2014.06.011. URL http: //www.ncbi.nlm.nih.gov/pubmed/24984220.

SUNNY-ROBERTS EO, OTUNOLA ET \& IWAKUN BT. 2004. An evaluation of some quality parameters of a laboratory-prepared fermented groundnut milk. Eur Food Res Technol 218(5): 452-455. doi:10.1007/s00217-004-0880-y.

SUPAVITITPATANA P, WIRJANTORO TI, APICHARTSRANGKOON A \& RAVIYAN P. 2008. Addition of gelatin enhanced gelation of corn-milk yogurt. Food Chem 106(1): 211-216. doi:10.1016/j.foodchem.2007.05.058.

TAMIME AY \& ROBINSON RK. 1999. Yoghurt-Science and Technology. International Journal of Dairy Technology. Woodhead Publishing Limited, Cambridge, UK, p. 20.

TSENG A \& ZHAO Y. 2013. Wine grape pomace as antioxidant dietary fibre for enhancing nutritional value and improving storability of yogurt and salad dressing. Food Chem 138(1): 356-365. doi:10.1016/j.foodchem.2012.09.148. URL http:// www.ncbi.nlm.nih.gov/pubmed/23265499.

YAAKOB H, AHMED NR, DAUD SK, MALEK RA \& RAHMAN RA. 2012. Optimization of ingredient and processing levels for the production of coconut yogurt using response surface methodology. Food Sci Biotechnol 21(4): 933-940. doi:10.1007/s10068-012-0123-0.

YU-POTH S, ETHERTON TD, REDDY CC, PEARSON TA, REED R, ZHAO G, JONNALAGADDA S, WAN Y \& KRIS-ETHERTON PM. 2000. Lowering dietary saturated fat and total fat reduces the oxidative susceptibility of LDL in healthy men and women. Human Nutrition and Metabolism 130(9): 2228-2237. doi:10.1093/jn/130.9.2228.

\section{How to cite}

GUL O, ATALAR I, MORTAS M, SARICAOGLU FT, BESIR A, GUL LB \& YAZICI F. 2022. Potential Use of High Pressure Homogenized Hazelnut Beverage for a Functional Yoghurt-Like Product. An Acad Bras Cienc 94: e20191172. DOI 10.1590/0001-3765202220191172.

Manuscript received on September 26, 2019; accepted for publication on December 3, 2019 


\section{OSMAN GUL ${ }^{1}$}

https://orcid.org/0000-0003-1620-4246

ILYAS ATALAR ${ }^{2}$

https://orcid.org/0000-0001-8560-0010

MUSTAFA MORTAS 3

https://orcid.org/0000-0002-0316-7768

FURKAN TURKER SARICAOGLU4

https://orcid.org/0000-0003-1173-5793

\section{AYSEGUL BESIR ${ }^{3}$}

https://orcid.org/0000-0002-6442-6807

LATIFE BETUL GUL ${ }^{5}$

https://orcid.org/0000-0002-4732-7727

FEHMI YAZICI ${ }^{3}$

https://orcid.org/0000-0001-9601-8843

${ }^{1}$ Department of Food Engineering, Faculty of Engineering and Architecture, Kastamonu University, Orgeneral Atilla Ateş Paşa Street, Kuzeykent Campus, Postal 37150, Kastamonu Center/Kastamonu, Turkey

${ }^{2}$ Department of Food Engineering, Faculty of Agriculture, Eskişehir Osmangazi University, Ziraat Street, Ali Numan Kıraç Campus, Postal 26160, Odunpazarı Village/Eskişehir, Turkey

${ }^{3}$ Department of Food Engineering, Faculty of Engineering, Ondokuz Mayis University, Kurupelit Campus, Postal 55139, Atakum Village/Samsun, Turkey

4 Department of Food Engineering, Faculty of Natural Sciences, Architecture and Engineering Bursa Technical University, Mimar Sinan Street, Mimar Sinan Campus, Postal 16310, Yıldırım Village/Bursa, Turkey

${ }^{5}$ Department of Food Engineering, Faculty of Engineering, Giresun University, Prof. Ahmet Taner Kışlalı Street, Güre Campus, Postal 28200, Giresun Center/Giresun, Turkey

Correspondence to: Osman Gul

E-mail: osmangul@kastamonu.edu.tr

\section{Author contributions}

Osman GUL designed research and wrote the manuscript with Ilyas ATALAR and Furkan Turker SARICAOGLU contributions. Ilyas ATALAR, Mustafa MORTAS, Furkan Turker SARICAOGLU, Aysegul BESIR and Latife Betul GUL performed the experiments and analyzed the data. Fehmi YAZICI discussed the results and commented on the manuscript. All authors provided critical feedback and contributed to the final version of the manuscript.

\section{(cc) BY}

